JURNAL SYNTAX FUSION

Vol 1 No 11, November 2021

E-ISSN: 2775-6440 | P-ISSN: 2808-7208

Jurnal Homepage https://fusion.rifainstitute.com

\title{
PENGARUH STRUKTUR KEPEMILIKAN MANAJERIAL, LEVERAGE, KOMPENSASI BONUS DAN UKURAN PERUSAHAAN TERHADAP MANAJEMEN LABA
}

\author{
Rachael Oktavia, Melvie Paramitha \\ Fakultas Ekonomi, Universitas Widya Kartika,Indonesia \\ Email: rachael.octavia@gmail.com,melvieparamithauwika@gmail.com
}

\begin{abstract}
Earnings Management is one of the efforts made by companies to manipulate the numbers in the financial statements so that the company's financial statements can be seen in good condition for investors and other stakeholders. This study aims to determine the effect of managerial ownership structure, leverage, bonus compensation and company size on earnings management in manufacturing companies listed in BEI 2017-2019. The sampling method in this study used purposive sampling so that the researchers found 55 companies that match the criteria in 2017-2019, so that this study analyzed as many as 165. The testing technique in this research is in the form of classical assumption test, normality test, autocorrelation test, multicollinearity test, heteroscedasticity test, determination coefficient test and $T$ test. The results of the study indicate that Managerial Ownership Structure, Leverage, Bonus Compensation and Company Size do not significantly influence earnings management.
\end{abstract}

Keywords: Managerial Ownership, Leverage, Bonus Compensation, Company Size and Earnings Management.

\begin{abstract}
Abstrak
Manajemen Laba adalah salah satu upaya yang dilakukan oleh perusahaan dalam memanipulasi angka-angka dalam laporan keuangan sehingga laporan keuangan perusahaan dapat terlihat dalam kondisi yang baik bagi investor dan pemangku kepentingan lainnya. Penelitian ini bertujuan untuk mengetahui Pengaruh Struktur Kepemilikan Manajerial, Leverage, Kompensasi Bonus Dan Ukuran Perusahaan Terhadap Manajemen Laba Pada Perusahan Manufaktur Yang Terdaftar Di BEI Tahun 2017-2019. Metode pengambilan sampel dalam penelitian ini menggunakan purposive sampling sehingga peneliti mendapatkan 55 perusahaan yang sesuai kriteria pada tahun 2017-2019, sehingga penelitian ini yang dianalisis sebanyak 165. Teknik pengujian dalam penelitian ini berupa uji asumsi klasik, uji normalitas, uji autokorelasi, uji multikolinearitas, uji heteroskedatisitas,uji koefisien determinasi dan uji T. Hasil penelitian yang menunjukan bahwa Struktur Kepemilikan Manajerial, Leverage, Kompensasi Bonus dan Ukuran Perusahaan tidak berpengaruh secara signifikan terhadap Manajemen Laba.
\end{abstract}

Kata kunci: Struktur Kepemilikan Manajerial, Leverage, Kompensasi Bonus, Ukuran

Copyright holder: Rachael Oktavia, Melvie Paramitha (2021)

DOI : https://doi.org/10.54543/fusion.v1i11.105

Published by : Rifa Institute 
Rachael Oktavia, Melvie Paramitha

Perusahaan dan Manajemen Laba.

Diterima: 19-10-2021

Direvisi: 10-11-2021

Diterbitkan: 20-11-2021

\section{Pendahuluan}

Persaingan dalam ekonomi pasar bebas saat ini menjadi semakin sengit. Hal ini disebabkan oleh terus bertambahnya jumlah perusahaan yang ada dan berkembang seiring dengan bertambahnya bidang usaha atau kegiatan ekonomi, yang menunjukkan bahwa permintaan pasar terus meningkat selama ini. Pasar modal memegang peranan penting dalam perekonomian suatu negara, karena pasar modal memiliki dua fungsi, yaitu sebagai sarana pembiayaan bagi perusahaan dan sebagai sarana bagi perusahaan untuk memperoleh dana dari masyarakat atau investor. Oleh karena itu, investor dan kreditur dapat memahami prospek masa depan perusahaan dan membantu mereka mengambil keputusan.

Di Indonesia terdapat pasar modal yang disebut BEI (Bursa Efek Indonesia) yang memegang peranan penting dalam perekonomian negara. Setiap emiten yang terdaftar di BEI memiliki laporan keuangan. Menurut Hery, laporan keuangan pada dasarnya merupakan hasil dari suatu proses akuntansi dan dapat digunakan sebagai alat untuk mengkomunikasikan data keuangan atau aktivitas perusahaan kepada stakeholders (Hery, 2017). Dengan kata lain, laporan keuangan ini berfungsi sebagai alat informasi yang menghubungkan perusahaan dengan pemangku kepentingan dan menunjukkan status keuangan perusahaan dan kinerja perusahaan.

Struktur kepemilikan merupakan faktor yang dapat mempengaruhi operasional perusahaan dan pada akhirnya mempengaruhi laporan keuangan, karena memiliki pengendalian. Struktur kepemilikan suatu perusahaan adalah kontrol pemegang saham atas perusahaan, yang diwakili oleh dewan direksi dan manajer. Struktur ekuitas dibagi menjadi dua bagian: ekuitas manajemen dan ekuitas institusional. Kepemilikan manajemen dapat menyelaraskan kepentingan pemegang saham dengan kepentingan manajer, karena manajer akan merasakan manfaat dari pengambilan keputusan dan menanggung resiko kerugian akibat keputusan yang salah (Agustia, 2013). Dengan kata lain, Pemegang Saham yang mendapat tempat dalam pengurus perseroan Bertindak sebagai direksi dan dewan direksi. Adanya ekuitas manajemen akan menyebabkan pengawasan terhadap kebijakan yang diambil oleh manajemen perusahaan.

Leverage adalah rasio total kewajiban terhadap total aset. Semakin tinggi tingkat leverage berarti semakin tinggi nilai hutang perusahaan. Perusahaan dengan rasio leverage yang lebih tinggi karena kewajiban yang lebih besar relatif terhadap aset perusahaan akan cenderung melakukan manipulasi dalam bentuk manajemen laba, yaitu meningkatkan aset pelaporan untuk meningkatkan daya tawar perusahaan dalam negosiasi utang dan mengurangi kekhawatiran kreditur dan keuntungan Diskon batas kredit.

Bonus adalah semua penghasilan berupa uang dan barang yang diterima karyawan secara langsung maupun tidak langsung sebagai balas jasa atau jasa yang 
diberikan kepada perusahaan. Kompensasi adalah istilah yang terkait dengan imbalan ekonomi yang diterima orang melalui hubungan kerja mereka dengan organisasi (Elfira, 2014).

Ukuran perusahaan merupakan gambaran kemampuan keuangan perusahaan dalam kurun waktu tertentu (Joni \& Lina, 2010). Besar kecilnya suatu perusahaan dapat dilihat dari besarnya aktivitas yang dimiliki perusahaan tersebut (Wimelda \& Marlinah, 2013). Perusahaan yang lebih besar biasanya mendapat perhatian lebih dari pihak eksternal seperti pemerintah, investor, atau kreditur, sehingga perusahaan akan lebih berhati-hati dalam mengelola laporan keuangannya. Besar kecilnya suatu perusahaan dapat dilihat dari banyaknya kegiatan yang dilakukan perusahaan, semakin besar perusahaan maka semakin banyak uang yang dikeluarkan. Besar kecilnya suatu perusahaan diukur dengan logaritma dari total aset yang dimiliki perusahaan dan dapat digunakan untuk operasional perusahaan. Perusahaan besar lebih memperhatikan publik, sehingga lebih berhati-hati dalam pelaporan keuangannya.

Manajemen laba adalah suatu tindakan yang dilakukan oleh manajemen perusahaan untuk mempengaruhi laba yang dilaporkan, yang dapat memberikan informasi tentang keuntungan ekonomi yang dapat merugikan kepentingan perusahaan dalam jangka panjang (Naftalia \& Marsono, 2013). Ketika manajer menggunakan penilaian dalam laporan keuangan dan persiapan transaksi untuk memodifikasi laporan keuangan, tujuannya adalah untuk memanipulasi kinerja ekonomi perusahaan atau untuk mempengaruhi hasil kesepakatan (kontrak) yang bergantung pada angka, perilaku manajemen laba akan terjadi.

Alasan peneliti memilih perusahaan manufaktur sebagai objek penelitian adalah karena perusahaan manufaktur yang terdaftar di Bursa Efek Indonesia terdiri dari beberapa sub sektor industri, yang dapat mencerminkan respon pasar modal secara keseluruhan. Perusahaan manufaktur juga memiliki jumlah perusahaan terbesar di Bursa Efek Indonesia. Selain itu, perusahaan manufaktur dipilih sebagai objek penelitian karena berdasarkan fakta yang dijelaskan, kasus-kasus yang melibatkan perusahaan manufaktur sedikit banyak lebih dominan dibandingkan perusahaan lain. Salah satu kasus manajemen laba di Indonesia adalah PT Garuda Indonesia Tbk. Laba bersih tahun 2018 sebesar US\$809.846 atau setara dengan Rp 11,49 miliar (kurs Rp 14.200/US\$). Total beban usaha perseroan mencapai US\$4,58 miliar pada 2019. Angka ini lebih tinggi US\$20608 juta dari total pendapatan tahun 2018 (Sumber: CNBC Indonesia 2019).

\section{Tinjauan Literatur}

1. Teori Keagenan (Agency Theory)

Jensen dan Meckling mendefinisikan hubungan keagenan sebagai kontrak antara pemilik (principal) dan manajer (agen) dengan mendelegasikan kekuasaan pengambilan keputusan kepada manajer untuk melakukan tugas-tugas untuk kepentingan pemilik (the prinsipal) (agen). Dalam praktiknya, manajer yang merupakan pengelola perusahaan tentu lebih mengetahui informasi internal dan prospek perusahaan di masa depan 
dibandingkan pemilik modal atau pemegang saham (Luayyi, 2010). Oleh karena itu, sebagai manajer, manajer berkewajiban untuk memberikan informasi kepada pemilik tentang status perusahaan. Namun dalam hal ini informasi yang disampaikan oleh manajer terkadang tidak sesuai dengan keadaan perusahaan yang sebenarnya

2. Laporan Keuangan

Menurut Bahri, laporan keuangan adalah ringkasan dari proses pencatatan transaksi keuangan yang terjadi selama periode pelaporan dan digunakan untuk menggambarkan tugas yang diberikan kepadanya oleh pemilik perusahaan. Laporan keuangan merupakan sumber informasi tentang status keuangan, kinerja, dan arus kas suatu entitas dalam periode waktu tertentu, yang dapat digunakan oleh pengguna laporan keuangan untuk mengambil keputusan ekonomi (Bahri, 2016). Dalam pengambilan keputusan yang memiliki konsekuensi ekonomi bagi investor, kreditor, karyawan, pemasok, pelanggan, pemerintah, dan masyarakat, dll, berbagai informasi yang terkandung dalam laporan keuangan diperlukan sebagai acuan evaluasi. Dan gunakan informasi keuangan untuk memprediksi pertumbuhan bisnis di masa depan. Agar penyusunan laporan keuangan sesuai dengan standar akuntansi akan membuat segala tindakan atau keputusan yang diambil oleh pemilik dalam usahanya dapat dipercaya dan lebih mudah.

\section{Struktur Kepemilikan Manajerial}

Menurut Sonya Majid Pracihara, kepemilikan manajemen adalah para pemegang saham manajemen yang terlibat aktif dalam pengambilan keputusan internal perusahaan, seperti direksi dan komisaris. Kepemilikan saham manajemen dapat menyelaraskan kepentingan pemegang saham dengan kepentingan manajer, karena manajer dapat memperoleh keuntungan langsung dari pengambilan keputusan, dan manajer juga menanggung risiko kerugian akibat kesalahan keputusan (Pracihara, 2016). Hal ini menunjukkan bahwa semakin besar proporsi saham yang dimiliki oleh manajer dalam suatu perusahaan, maka semakin besar pula kepentingan antara manajer dan pemegang saham, yang akan membuat kinerja perusahaan semakin baik.

Menurut Saputri dan Winarto, leverage adalah rasio yang mengukur kemampuan perusahaan untuk memenuhi kewajiban jangka panjang. Semakin besar hutang suatu perusahaan dibandingkan dengan asetnya, maka semakin besar pula risiko yang dihadapi perusahaan dalam kewajiban pembayarannya (Saputri \& Winarto, 2019). Semakin besar leverage maka semakin besar pula ketergantungan perusahaan terhadap pihak luar (kreditur), dan semakin besar pula beban biaya utang (biaya bunga) yang harus dibayar perusahaan.

\section{Kompensasi Bonus}

Bonus adalah semua penghasilan berupa uang dan barang yang diterima karyawan secara langsung maupun tidak langsung sebagai balas jasa atau jasa yang diberikan kepada perusahaan. Kompensasi adalah istilah yang terkait dengan imbalan finansial yang diterima orang melalui hubungan kerja mereka dengan organisasi (Elfira, 2014). Menurut Elfira juga menjelaskan bahwa remunerasi adalah segala sesuatu yang diberikan atau dianggap balas jasa yang adil dan pantas kepada pekerja dalam rangka 
mencapai tujuan organisasi.

\section{Ukuran Perusahan}

Menurut Ira Karmila, semakin besar perusahaan, semakin besar kecenderungan untuk menggunakan modal asing. Hal ini dikarenakan perusahaan besar membutuhkan dana yang banyak untuk menunjang operasionalnya, jika dana sendiri tidak mencukupi, pilihan lain adalah menggunakan modal asing (Ira, Inge Lengga Sari, \& Fatahurrazak, 2019). Ukuran perusahaan biasanya mencerminkan penilaian pemegang saham dari semua aspek kinerja keuangan masa lalu dan prediksi mereka untuk masa depan. Semakin besar aset perusahaan, semakin stabil status keuangan perusahaan, dan semakin mudah memperoleh dana dibandingkan perusahaan dengan aset lebih rendah. Besar kecilnya suatu perusahaan menunjukkan pengalaman dan kapabilitas suatu perusahaan, yang menentukan kemampuan dan tingkat risiko dalam mengelola investasi yang diberikan kepada pemegang saham untuk meningkatkan kemakmurannya.

\section{Manajemen Laba}

Manajemen laba adalah proses yang disengaja, dan standar akuntansi keuangan membatasi pelaporan pendapatan langsung sampai batas tertentu. Manajemen laba digunakan untuk membuat laporan keuangan yang baik. Tentunya karena kondisi keuangan yang sehat, investor tertarik untuk membeli saham perusahaan tersebut karena dinilai memiliki kinerja yang baik (Indrayanti \& Wirakusuma, 2017). Selama manajemen laba dilakukan dalam koridor peluang, manajemen laba bukanlah hal yang merugikan.Manajemen laba tidak selalu diartikan dengan proses memanipulasi laporan keuangan, karena ada beberapa metode yang dapat digunakan daripada dilarang.

\section{Metode Penelitian}

Variabel yang digunakan dalam penelitian ini adalah variabel bebas dan variabel terikat. Variabel bebas terdiri dari variabel struktur kepemilikan manajerial, leverage, kompensasi bonus dan ukuran perusahaan (Sari \& Khafid, 2020). Sedangkan variabel terikat pada penelitian ini adalah manajemen laba pada perusahaan Manufaktur yang terdaftar di Bursa Efek Indonesia (BEI). Berdasarkan hipotesis yang ditetapkan, kerangka konseptual dalam penelitian ini adalah sebagai berikut:

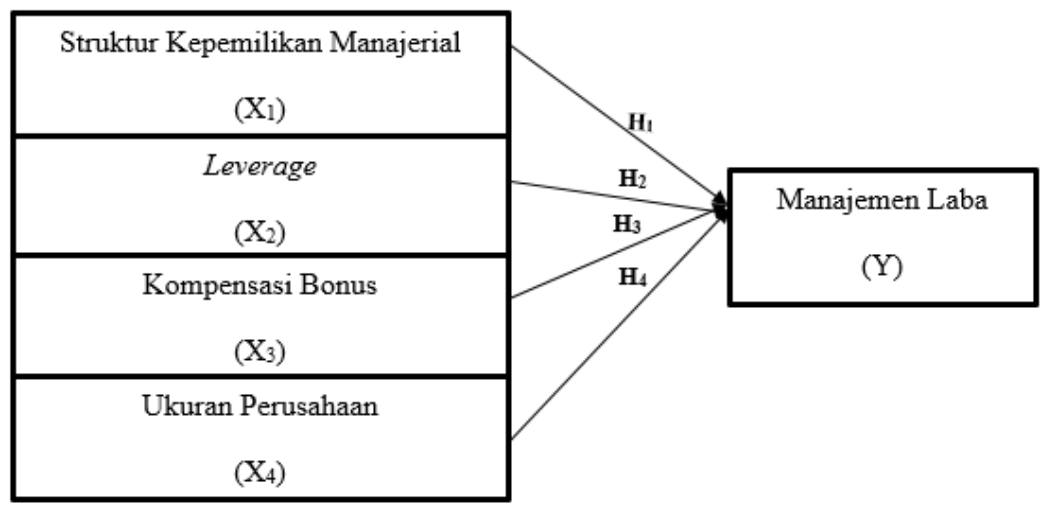


Gambar 1 Kerangka Konseptual

\section{Definisi Operasional Variabel}

\section{Struktur Kepemilikan Manajerial}

Struktur kepemilikan manajemen merupakan syarat bagi manajer untuk ikut serta dalam struktur permodalan perusahaan, dengan kata lain manajer memiliki peran ganda sebagai manajer dan pemegang saham dalam perusahaan. Dalam penelitian ini, pengukuran yang digunakan untuk mengelola variabel struktural kepemilikan menggunakan rumus:

$$
\mathrm{KPMJ}=\frac{\text { Jumlah Saham yang dimiliki pihak manajemen }}{\text { Jumlah saham yang beredar }}
$$

\section{Leverage}

Leverage adalah rasio yang menunjukkan bagaimana suatu perusahaan dapat mengelola hutangnya untuk mendapatkan keuntungan, dan juga dapat membayar hutangnya. Dalam penelitian ini, rumus yang digunakan untuk pengukuran variabel leverage:

$$
\mathrm{DAR}=\frac{\text { Total Utang }}{\text { Aktiva (assets) }}
$$

\section{Kompensasi Bonus}

Bonus adalah imbalan yang diberikan oleh pemilik perusahaan kepada pengurus perusahaan pengelola atas pencapaian kinerja yang baik dan melebihi kinerja yang telah ditentukan. Dengan kata lain, semakin besar pencapaian melebihi tujuan yang ada, maka semakin besar kemungkinan perusahaan akan memberikan bonus. Pengukuran yang digunakan dalam penelitian ini menggunakan variabel dummy, dimana nilai 1 menunjukkan perusahaan yang memberikan kompensasi bonus, dan nilai 0 menunjukkan perusahaan yang tidak memberikan kompensasi bonus.

4. Ukuran Perusahaan

Semakin besar aset perusahaan, semakin stabil status keuangan perusahaan, dan semakin mudah memperoleh dana dibandingkan perusahaan dengan aset lebih rendah. Dalam penelitian ini, rumus yang digunakan untuk pengukuran variabel ukuran perusahaan:

\section{Populasi dan Sampel}

$$
\text { Size }=\text { Ln Total Asset }
$$

Populasi adalah keseluruhan objek penelitian. Totalitas penelitian ini adalah perusahaan manufaktur yang terdaftar di Bursa Efek Indonesia (BEI) dari tahun 2017 hingga 2019, dengan jumlah 175 perusahaan. Sampel adalah bagian dari subjek atau objek dalam kelompok yang diteliti, sehingga dapat mewakili kelompok tersebut. Metode pengambilan sampel penelitian ini menggunakan teknik purposive sampling, yaitu teknik pengambilan sampel dengan pertimbangan tertentu. Standar yang digunakan sebagai sampel penelitian adalah sebagai berikut:

1. Perusahaan manufaktur yang menerbitkan laporan keuangan tahun 2017-2019 secara berturut-turut. 
2. Perusahaan manufaktur yang memiliki data struktur kepemilikan manajerial tahun 2017-2019 secara berturut-turut

Berdasarkan kriteria tersebut, sampel yang digunakan dalam penelitian ini sebanyak 55 perusahaan yang sesuai dengan kriteria sampel. Berikut rincian sampel yang sesuai dengan kriteria :

Tabel 1 Pemilihan Sampel

\begin{tabular}{lc}
\hline \multicolumn{1}{c}{ Keterangan } & Jumlah \\
\hline $\begin{array}{l}\text { Perusahaan manufaktur yang terdaftar di Bursa Efek } \\
\text { Indonesia selama periode 2017-2019 }\end{array}$ & 170 \\
\hline Kriteria: & $(28)$ \\
\hline $\begin{array}{l}\text { 1. Perusahaan manufaktur yang tidak menerbitkan } \\
\text { laporan keuangan tahun 2017-2019 secara berturut-turut. }\end{array}$ & $(87)$ \\
\hline $\begin{array}{l}\text { 2. Perusahaan manufaktur yang tidak memiliki data } \\
\text { struktur kepemilikan manajerial tahun 2017-2019 secara } \\
\text { berturut-turut }\end{array}$ & 55 \\
\hline Jumlah Perusahaan yang terpilih menjadi sampel & $\mathbf{1 6 5}$ \\
\hline Jumlah Sampel total selama periode penelitian
\end{tabular}

\section{Teknik Analisis Data}

Penelitian ini diuji dengan menggunakan bantuan program IBM Software Statistical Package for the Social Sciences (SPSS) versi 26. Sebelum melakukan teknik analisis data, peneliti perlu memperhitungkan variabel terlebih dahulu. Ada beberapa langkah untuk melakukan perhitungan yaitu:

1. Menghitung Struktur Kepemilikan Manajerial yang diukur dengan menggunakan jumlah saham yang dimiliki oleh pihak manajemen dibagi dengan jumlah saham yang beredar.

2. Menghitung Leverage yang diukur dengan menggunakan Debt To Asset Ratio.

3. Menghitung Kompensasi Bonus dengan menggunakan variabel dummy yaitu dengan memberikan skor 1 untuk perusahaan yang memberikan bonus kepada manajemen, dan skor 0 untuk perusahaan yang tidak memberi memberikan bonus kepada manajemen.

4. Menghitung Ukuran Perusahaan yang diukur dengan menggunakan logaritma total aset.

\section{Hasil dan Pembahasan}

\section{A. Uji Asumsi Klasik}

\section{Statistik Deskriptif}

Tabel 4.22 Tabel Hasil Statistik Deskriptif 


\begin{tabular}{|l|r|r|r|r|r|}
\hline \multicolumn{7}{|c|}{ Descriptive Statistics } \\
\hline & \multicolumn{1}{|c|}{$\mathrm{N}$} & Minimum & Maximum & \multicolumn{1}{c|}{ Mean } & $\begin{array}{c}\text { Std. } \\
\text { Deviation }\end{array}$ \\
\hline $\mathrm{kpm}$ & 165 &, 000 & 1,000 &, 14168 &, 202698 \\
\hline $\mathrm{Ivg}$ & 165 &, 000 & 1,886 &, 43516 &, 241639 \\
\hline $\mathrm{kb}$ & 165 & 0 & 1 &, 81 &, 397 \\
\hline $\mathrm{up}$ & 165 & 20,630 & 33,495 & 27,91648 & 1,989875 \\
\hline $\mathrm{mb}$ & 165 &,- 584 &, 459 &, 02005 &, 097242 \\
\hline Valid N (listwise) & 165 & & & & \\
\hline
\end{tabular}

Sumber : Diolah oleh peneliti dari SPSS 26

Tabel 4.22 diatas menunjukkan bahwa penelitian ini memiliki sampel sebanyak 165 perusahaan selama 3 tahun waktu observasi yang dapa

t dilihat pada nilai N. Serta nilai Minimum, Maksimum, Mean dan Standar Deviasi variabel Struktur Kepemilikan Manajerial (KPM), Leverage (LVG), Kompensasi Bonus (KB), Ukuran Perusahaan (UP) dan Manajemen Laba (MB).

\section{Uji Normalitas Data}

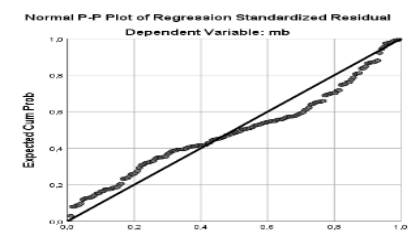

\section{Gambar 4.1 Grafik Normal P-P Plot}

Sumber : Diolah oleh peneliti dari SPSS 26

Dari hasil grafik Normal P-P Plot di atas dapat dilihat bahwa titik-titik yang terdapat pada grafik tersebut menyebar di sekitar garis diagonal dan mengikuti garis, sehingga dapat disimpulkan bahwa model regresi tersebut telah memenuhi asumsi normalitas dalam penelitian ini.

\section{Uji Autokorelasi}

Tabel 4.23 Tabel Uji Autokorelasi Durbin-Watson

\begin{tabular}{cccccc}
\hline \multicolumn{5}{c}{ Model Summary $^{\mathbf{b}}$} \\
\hline Mo & $\mathrm{R}$ & $\mathrm{R}$ & $\begin{array}{c}\text { Adjusted } \\
\text { del }\end{array}$ & $\begin{array}{c}\text { Squar } \\
\text { R Square } \\
\text { of the } \\
\text { Estimate }\end{array}$ & $\begin{array}{c}\text { Durbin- } \\
\text { Watson }\end{array}$ \\
\hline 1 &, $085^{\text {a }}$ &, 007 &,- 018 &, 098095 & 2,165 \\
\hline
\end{tabular}

a. Predictors: (Constant), up, kb, lvg, kpm

b. Dependent Variable: mb

Sumber : Diolah oleh peneliti dari SPSS 26

Berdasarkan Tabel 4.22 di atas, dihasilkan Durbin-Watson sebesar 2,165. Kesimpulan yang dapat diambil oleh peneliti dari hasil penelitian tersebut adalah tidak terjadinya autokorelasi sesuai dengan teori yang ada.

\section{Uji Multikolinearitas}

Tabel 4.24 Tabel Uji Multikolinearitas 
Pengaruh Struktur Kepemilikan Manajerial Perusahaan Terhadap Manajemen Laba

\begin{tabular}{|c|c|c|c|c|c|c|c|c|}
\hline \multicolumn{9}{|c|}{ Coefficients $^{\mathrm{a}}$} \\
\hline \multirow{2}{*}{\multicolumn{2}{|c|}{ Model }} & \multicolumn{2}{|c|}{$\begin{array}{l}\text { Unstandardized } \\
\text { Coefficients }\end{array}$} & \multirow{2}{*}{$\begin{array}{c}\begin{array}{c}\text { Standardiz } \\
\text { ed } \\
\text { Coefficient } \\
\text { s }\end{array} \\
\text { Beta }\end{array}$} & \multirow[t]{2}{*}{$t$} & \multirow[t]{2}{*}{ Sig. } & \multicolumn{2}{|c|}{$\begin{array}{c}\text { Collinearity } \\
\text { Statistics }\end{array}$} \\
\hline & & B & Std. Error & & & & Tolerance & VIF \\
\hline \multirow[t]{5}{*}{1} & $\begin{array}{l}\text { (Consta } \\
\text { nt) }\end{array}$ & ,044 & ,117 & & 375 & ,708 & & \\
\hline & $\mathrm{kpm}$ &,- 042 &, 041 &,- 089 & $-1,043$ & ,298 & 862 & 1,160 \\
\hline & $\operatorname{lvg}$ &, 011 & 033 &, 027 & 325 &, 745 & 917 & 1,091 \\
\hline & $\mathrm{kb}$ &, 000 & ,020 &, 002 & ,019 & 985 & 943 & 1,061 \\
\hline & up &,- 001 &, 004 &,- 017 & -196 & 845 & 862 & 1,160 \\
\hline
\end{tabular}

Sumber : Diolah oleh peneliti dari SPSS 26

Dari hasil uji multikolinearitas diatas dapat dilihat bahwa nilai tolerance dan VIF masing-masing variabel adalah 1,160 (KPM); 1.091 (LVG); 1.061(KB); 1,160(UP). Dengan demikian kesimpulan yang dapat ditarik oleh peneliti adalah tidak terjadi multikolinearitas dalam penelitian ini karena nilai VIF tolerance dibawah 0,10 atau nilai VIF dibawah 10.

\section{Uji Heteroskedatisitas}

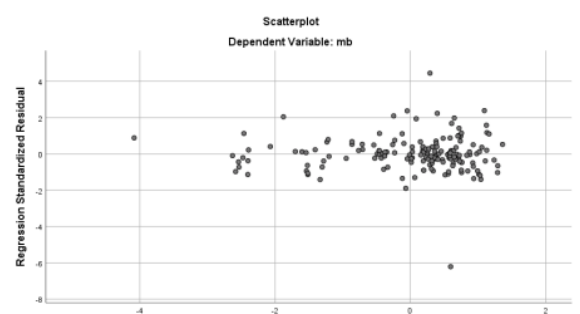

Gambar 4.2 Uji Heteroskedatisitas (Scatterplot)

Sumber: Diolah oleh peneliti dari SPSS 26

Berdasarkan hasil uji heterokedastisitas diatas tersebut terlihat titik-titik menyebar secara acak dan tidak membentuk pola tertentu serta tersebar baik di atas maupun di bawah angka 0 pada sumbu Y. Oleh karena itu, dapat disimpulkan bahwa tidak terjadi heteroskedastisitas pada penelitian ini.

\section{B. Analisis Regresi Berganda}

Tabel 4.26 Tabel Hasil Analisis Regresi Berganda

\begin{tabular}{|c|c|c|c|c|c|c|c|c|}
\hline \multicolumn{9}{|c|}{ Coefficients $^{\mathrm{a}}$} \\
\hline \multirow{2}{*}{\multicolumn{2}{|c|}{ Model }} & \multicolumn{2}{|c|}{$\begin{array}{l}\text { Unstandardized } \\
\text { Coefficients }\end{array}$} & \multirow{2}{*}{$\begin{array}{c}\text { Standardiz } \\
\text { ed } \\
\text { Coefficient } \\
\text { S } \\
\text { Beta }\end{array}$} & \multirow[t]{2}{*}{ t } & \multirow[t]{2}{*}{ Sig. } & \multicolumn{2}{|c|}{$\begin{array}{l}\text { Collinearity } \\
\text { Statistics }\end{array}$} \\
\hline & & B & Std. Error & & & & Tolerance & VIF \\
\hline \multirow[t]{5}{*}{1} & $\begin{array}{l}\text { (Consta } \\
\text { nt) }\end{array}$ & ,044 & 117 & & ,375 & .708 & & \\
\hline & $\mathrm{kpm}$ &,- 042 & 041 &,- 089 & $-1,043$ & 298 & 862 & 1,160 \\
\hline & Ivg &, 011 & 033 &, 027 & 325 & ,745 & 917 & 1,091 \\
\hline & $\mathrm{kb}$ &, 000 &, 020 & ,002 &, 019 & ,985 & 943 & 1,061 \\
\hline & up &,- 001 & .004 &,- 017 & -196 & 845 & 862 & 1,160 \\
\hline
\end{tabular}

Sumber : Diolah oleh peneliti dari SPSS 26

Berdasarkan hasil analisis diatas dapat dijelaskan melalui model regresi sebagai 
berikut:

$\mathrm{Y}=0,044-0,042$ Kepemilikan Manajerial $+0,011$ Leverage $+0,000$ Kompensasi Bonus - 0001 Ukuran Perusahaan

Interpretasi dari koefisien persamaan regresi dapat dijelaskan sebagai berikut :

A. Konstanta sebesar 0,044, menunjukkan bahwa jika variabel bebas dianggap konstan, maka rata-rata nilai manajemen laba yang dimiliki perusahaan sebesar 0,044 .

B. Koefisien regresi struktur kepemilikan manajerial bertanda negatif menunjukkan bahwa setiap peningkatan struktur kepemilikan manajerial perusahaan sebesar 1 akan menurunkan manajemen laba sebesar 0,042.

C. Koefisien regresi leverage bertanda positif menunjukkan bahwa setiap peningkatan leverage perusahaan sebesar 1 akan meningkatkan manajemen laba sebesar 0,011.

D. Koefisien regresi kompensasi bonus bertanda positif menunjukkan bahwa setiap peningkatan kompensasi bonus sebesar 1 maka akan meningkatkan manajemen laba sebesar 0,000 .

E. Koefisien regresi ukuran perusahaan bertanda negatif menunjukkan bahwa setiap peningkatan ukuran perusahaan sebesar 1 maka akan meningkatkan manajemen laba sebesar 0,001 .

\section{Uji Koefisien Determinasi $\left(\mathbf{R}^{2}\right)$}

Tabel 4.27 Tabel Uji Koefisien Determinasi $\left(\mathrm{R}^{2}\right)$

\begin{tabular}{|c|c|c|c|c|}
\hline \multicolumn{5}{|c|}{ Model Summary ${ }^{\mathrm{b}}$} \\
\hline $\begin{array}{l}\text { Mo } \\
\text { del }\end{array}$ & $\mathrm{R}$ & $\begin{array}{c}\mathrm{R} \\
\text { Square }\end{array}$ & $\begin{array}{l}\text { Adjusted } \\
\text { R Square }\end{array}$ & $\begin{array}{l}\text { Std. Error } \\
\text { of the } \\
\text { Estimate }\end{array}$ \\
\hline 1 &, $085^{\mathrm{a}}$ & ,007 &,- 018 & ,098095 \\
\hline a. $\mathrm{P}$ & ors: ( & istant), & $\mathrm{up}, \operatorname{lvg}, \mathrm{kp}$ & \\
\hline
\end{tabular}

Dari tabel di atas dapat diketahui nilai $\mathrm{R}^{2}$ sebesar 0,007 yaitu variabilitas variabel manajemen laba yang dijelaskan oleh variabel bebas seperti struktur kepemilikan saham manajemen, leverage, bonus, dan ukuran perusahaan dalam penelitian ini sebesar $0,7 \%$, sedangkan sisanya 99,3\% dijelaskan oleh variabel. -Variabel penelitian di luar model.

\section{Uji T}

Tabel 4.28 Tabel Hasil Uji T 
Pengaruh Struktur Kepemilikan Manajerial Perusahaan Terhadap Manajemen Laba

\begin{tabular}{|c|c|c|c|c|c|c|c|c|}
\hline \multicolumn{9}{|c|}{ Coefficients $^{\mathrm{a}}$} \\
\hline \multirow{2}{*}{\multicolumn{2}{|c|}{ Model }} & \multicolumn{2}{|c|}{$\begin{array}{l}\text { Unstandardized } \\
\text { Coefficients }\end{array}$} & \multirow{2}{*}{$\begin{array}{c}\begin{array}{c}\text { Standardiz } \\
\text { ed } \\
\text { Coefficient } \\
\text { s }\end{array} \\
\text { Beta }\end{array}$} & \multirow[t]{2}{*}{$t$} & \multirow[t]{2}{*}{ Sig. } & \multicolumn{2}{|c|}{$\begin{array}{l}\text { Collinearity } \\
\text { Statistics }\end{array}$} \\
\hline & & $\mathrm{B}$ & Std. Error & & & & Tolerance & VIF \\
\hline \multirow[t]{5}{*}{1} & $\begin{array}{l}\text { (Consta } \\
\text { nt) }\end{array}$ &, 044 & ,117 & & .375 & ,708 & & \\
\hline & $\mathrm{kpm}$ &,- 042 & ,041 &,- 089 & $-1,043$ & 298 & 862 & 1,160 \\
\hline & $\operatorname{lvg}$ & 011 & ,033 & 027 & .325 & ,745 & ,917 & 1,091 \\
\hline & $\mathrm{kb}$ &, 000 & 020 & 002 &, 019 & ,985 & 943 & 1,061 \\
\hline & up &,- 001 & .004 &,- 017 & -196 & 845 & 862 & 1,160 \\
\hline
\end{tabular}

Sumber : Diolah oleh peneliti dari SPSS 26

Berdasarkan hasil $t$ dengan menggunakan program SPSS 20 yang dilakukan oleh peneliti maka dapat diperoleh hasil dari pengaruh masing-masing variabel bebas terhadap variabel terikat sebagai berikut :

A. Kepemilikan Manajerial. Dari hasil perhitungan melalui program SPSS 26 diperoleh hasil nilai signifikan sebesar 0,298 > 0,05, maka dapat disimpulkan bahwa variabel kepemilikan manajerial tidak berpengaruh secara signifikan terhadap manajemen laba. Dengan demikian, maka $\mathrm{H}_{1}$ ditolak

B. Leverage. Dari hasil perhitungan melalui program SPSS 26 diperoleh hasil nilai signifikan sebesar 0,745>0,05, maka dapat disimpulkan bahwa variabel leverage tidak berpengaruh secara signifikan terhadap manajemen laba. Dengan demikian, maka $\mathrm{H}_{2}$ ditolak.

C. Kompensasi Bonus. Dari hasil perhitungan melalui program SPSS 26 diperoleh hasil nilai signifikan sebesar 0,985 > 0,05, maka dapat disimpulkan bahwa variabel kompensasi bonus tidak berpengaruh secara signifikan terhadap manajemen laba. Dengan demikian, maka $\mathrm{H}_{3}$ ditolak

D. Ukuran Perusahaan. Dari hasil perhitungan melalui program SPSS 26 diperoleh hasil nilai signifikan sebesar 0,845>0,05, maka dapat disimpulkan bahwa variabel ukuran perusahaan tidak berpengaruh secara signifikan terhadap manajemen laba.

Dengan demikian, maka $\mathrm{H}_{4}$ ditolak.

\section{Interpretasi Hasil Penelitian}

\section{Pengaruh Kepemilikan Manajerial terhadap Manajemen Laba pada Perusahaan Manufaktur Periode 2017 - 2019}

Hasil tersebut memiliki nilai signifikansi 0,298 > 0,05 sehingga dapat disimpulkan bahwa variabel kepemilikan manajemen tidak berpengaruh signifikan terhadap manajemen laba perusahaan manufaktur dari tahun 2017 sampai dengan tahun 2019, sehingga $\mathrm{H} 1$ ditolak. Hasil ini didukung oleh penelitian yang dilakukan oleh Guna dan Herawaty (2010) dan Pradipta (2011) yang menunjukkan bahwa kepemilikan manajemen tidak berpengaruh terhadap manajemen laba. Menurut Hery, ekuitas kurang dari $20 \%$ tidak akan berdampak signifikan terhadap keputusan perusahaan. Kepemilikan saham manajemen dapat menyelaraskan kepentingan pemegang saham dengan kepentingan manajer, karena manajer secara langsung merasakan manfaat dari keputusan tersebut (Hery, 2017). Hal ini menunjukkan bahwa semakin besar rasio 
kepemilikan saham manajemen dalam perusahaan, maka semakin dapat menyatukan kepentingan manajer dan pemegang saham, sehingga kinerja perusahaan akan semakin baik. Kepentingan antara pemilik (prinsipal) dan manajer (agen). Oleh karena itu, perannya lebih kecil dalam pengambilan keputusan manajemen perusahaan, termasuk manajemen laba. Hal ini menyebabkan variabel kepemilikan saham manajemen tidak berpengaruh signifikan terhadap perilaku manajemen laba perusahaan manufaktur yang terdaftar di Bursa Efek Indonesia tahun 2017-2019. Oleh karena itu, H1 yang diajukan peneliti adalah pengaruh kepemilikan saham manajemen terhadap laba. manajemen perusahaan manufaktur 2017-2019 Terdaftar di Bursa Efek Indonesia tahun 2016, tidak menerima atau menolak.

\section{Pengaruh Leverage terhadap Manajemen Laba pada Perusahaan Manufaktur Periode 2017 - 2019}

Hasil tersebut memiliki nilai signifikansi 0,745 > 0,05 sehingga dapat disimpulkan bahwa variabel leverage tidak berpengaruh signifikan terhadap manajemen laba perusahaan manufaktur dari tahun 2017 sampai 2019, sehingga H2 ditolak. Hasil ini didukung oleh penelitian Jao dan Gagaring (2011), Wika (2011) dan Elfira (2014), yang menunjukkan bahwa leverage tidak berpengaruh terhadap manajemen laba. Perusahaan dengan tingkat leverage yang tinggi menunjukkan bahwa kewajiban perusahaan lebih besar daripada aset perusahaan, dan ketidakmampuan perusahaan untuk memenuhi kewajibannya membawa risiko dan tekanan yang besar bagi perusahaan. Investor akan lebih memilih perusahaan dengan leverage yang lebih rendah. Artinya tingkat leverage tidak akan mempengaruhi manajemen laba. Hal ini menjelaskan bahwa perusahaan dengan hutang yang tinggi tidak dapat dijadikan alasan untuk melakukan manajemen laba perusahaan, karena perusahaan dengan total hutang yang tinggi masih harus mempertimbangkan resiko tidak dapat memenuhi kewajiban hutangnya. Hal ini mengakibatkan variabel leverage tidak berpengaruh signifikan terhadap perilaku manajemen laba perusahaan manufaktur yang terdaftar di BEI dari tahun 2017 hingga 2019. Oleh karena itu, H2 yang diajukan peneliti yaitu leverage berpengaruh terhadap manajemen laba perusahaan manufaktur yang terdaftar di BEI. perusahaan. Pada 20172019, itu tidak dapat diterima.

\section{Pengaruh Kompensasi Bonus terhadap Manajemen Laba pada Perusahaan Manufaktur Periode 2016 - 2019}

Hasil tersebut memiliki nilai signifikansi 0,985 > 0,05 sehingga dapat disimpulkan bahwa variabel Bonus Compensation tidak berpengaruh signifikan terhadap manajemen laba perusahaan manufaktur dari tahun 2017 sampai dengan 2019, sehingga Hipotesis H3 ditolak. Hasil ini didukung oleh penelitian Dustriyani \& Nazar (2015) dan Ferdiansyah (2014), yang menunjukkan bahwa kompensasi bonus tidak berpengaruh terhadap manajemen laba. Dapat dilihat bahwa bonus tidak selalu menjadi motivasi bagi direksi untuk melakukan manajemen laba. Besarnya remunerasi bukanlah motivasi utama bagi direksi dalam mengelola laba. Tindakan peluang manajemen laba yang mungkin diambil manajemen tidak sepadan dengan risiko yang mereka tanggung. Memberikan kompensasi lain yang lebih tinggi dari bonus, seperti fasilitas dan 
tunjangan, serta mendukung manajer untuk tetap bersikap apa adanya atau melaporkan laporan keuangan perusahaan. Hal ini membuat variabel kompensasi bonus tidak memiliki pengaruh yang signifikan terhadap perilaku manajemen laba perusahaan manufaktur yang terdaftar di BEI dari tahun 2017 hingga 2019. Oleh karena itu, H3 yang diusulkan oleh peneliti adalah leverage untuk mempengaruhi manajemen laba perusahaan manufaktur yang terdaftar di BEI dari tahun 2017 hingga 2019- 2019, tidak menerima atau Menolak.

\section{Pengaruh Ukuran Perusahaan terhadap Manajemen Laba pada Perusahaan Manufaktur Periode 2016 - 2019}

Hasil tersebut memiliki nilai signifikansi sebesar 0,845>0,05 sehingga dapat disimpulkan bahwa variabel ukuran perusahaan tidak berpengaruh signifikan terhadap manajemen laba perusahaan manufaktur dari tahun 2017 sampai 2019, sehingga H4 ditolak. Hasil ini didukung oleh penelitian Jao dan Gagaring yang menunjukkan bahwa ukuran perusahaan tidak berpengaruh signifikan terhadap manajemen laba (Jao \& Pagalung, 2011), dan hasil ini tidak didukung oleh penelitian Mahiswari dan Nugroho yang menunjukkan bahwa ukuran perusahaan Mempengaruhi manajemen laba Semakin besar perusahaan, semakin kecil tindakan manajemen laba (Mahiswari \& Nugroho, 2014). Hal ini dikarenakan perusahaan besar semakin banyak mendapat perhatian dari investor untuk memberikan laporan keuangan yang handal, sedangkan perusahaan besar semakin banyak mendapatkan perhatian dari investor, menuntut perusahaan untuk selalu melaporkan laba yang baik. Hal ini menunjukkan bahwa variabel ukuran perusahaan tidak berpengaruh signifikan terhadap perilaku manajemen laba perusahaan manufaktur yang terdaftar di Bursa Efek Indonesia dari tahun 2017 sampai 2019. Oleh karena itu, H4 yang diajukan peneliti adalah bahwa leverage berpengaruh terhadap laba manufaktur. perusahaan yang terdaftar di Bursa Efek Indonesia.Mengelola bursa efek 2017-2019, dan tidak menerima atau menolaknya.

\section{Kesimpulan}

Dari hasil penelitian dan pembahasan yang telah dilakukan oleh peneliti, maka kesimpulan yang dapat ditarik adalah struktur kepemilikan manajerial terhadap manajemen laba memiliki nilai signifikan sebesar 0,298 > 0,05 maka dapat disimpulkan bahwa variabel Kepemilikan Manajerial tidak berpengaruh secara signifikan terhadap Manajemen Laba. Leverage terhadap manajemen laba memiliki nilai signifikan sebesar $0,745>0,05$ maka dapat disimpulkan bahwa variabel Leverage tidak berpengaruh secara signifikan terhadap Manajemen Laba.

Kompensasi Bonus terhadap manajemen laba memiliki nilai signifikan sebesar sebesar 0,985 > 0,05 maka dapat disimpulkan bahwa variabel Kompensasi Bonus tidak berpengaruh secara signifikan terhadap Manajemen Laba. Ukuran perusahaan terhadap manajemen laba memiliki nilai signifikan sebesar sebesar 0,845>0,05 maka dapat disimpulkan bahwa variabel Ukuran Perusahaan tidak berpengaruh secara signifikan terhadap manajemen laba. 
Rachael Oktavia, Melvie Paramitha

\section{BIBLIOGRAFI}

Agustia, Dian. (2013). Pengaruh faktor good corporate governance, free cash flow, dan leverage terhadap manajemen laba. Jurnal Akuntansi Dan Keuangan, 15(1), 27-42. Google Scholar

Bahri, Syaiful. (2016). Pengantar akuntansi berdasarkan SAK ETAP dan IFRS. Google Scholar

Elfira, Anisa. (2014). Pengaruh Kompensasi Bonus Dan Leverage Terhadap Manajemen Laba (Studi Empiris Pada Perusahaan Manufaktur yang Terdaftar di Bursa Efek Indonesia Tahun 2009-2012). Jurnal Akuntansi, 2(2). Google Scholar

Hery, S. E. (2017). Teori Akuntansi: Pendekatan Konsep dan Analisis. Gramedia Widiasarana Indonesia. Google Scholar

Indrayanti, Ni Putu Ayu Desy, \& Wirakusuma, Made Gede. (2017). Pengaruh manajemen laba pada return saham dengan kualitas audit dan corporate governance sebagai variabel pemoderasi. E-Jurnal Akuntansi Universitas Udayana, 20(3), 1762-1790. Google Scholar

Ira, Karmila, Inge Lengga Sari, Munthe, \& Fatahurrazak, Fatahurrazak. (2019). Pengaruh Laba Kotor, Total Arus Kas, Ukuran Perusahaan, Dan Profitabilitas, Terhadap Return Saham (Studi Pada Perusahaan Manufaktur Yang Terdaftar Di Bursa Efek Indonesia Periode 2014-2017). Universitas Maritim Raja Ali Haji. Google Scholar

Jao, Robert, \& Pagalung, Gagaring. (2011). Corporate governance, ukuran perusahaan, dan leverage terhadap manajemen laba perusahaan manufaktur Indonesia. Jurnal Akuntansi Dan Auditing, 8(1), 43-54. Google Scholar

Joni, Joni, \& Lina, Lina. (2010). Faktor-faktor yang mempengaruhi struktur modal. Jurnal Bisnis Dan Akuntansi, 12(2), 82-97. Google Scholar

Luayyi, Sri. (2010). Teori keagenan dan manajemen laba dari sudut pandang etika manajer. EL MUHASABA: Jurnal Akuntansi (e-Journal), 1(2). Google Scholar

Mahiswari, Raras, \& Nugroho, Paskah Ika. (2014). Pengaruh mekanisme corporate governance, ukuran perusahaan dan leverage terhadap manajemen laba dan kinerja Keuangan. Jurnal Ekonomi Dan Bisnis, 17(1), 1-20. Google Scholar

Naftalia, Veliandina Chivan, \& Marsono, Marsono. (2013). Pengaruh Leverage terhadap Manajemen Laba dengan Corporate Governance sebagai Variabel Pemoderasi. Fakultas Ekonomika dan Bisnis. Google Scholar

Pracihara, Sonya Majid. (2016). Pengaruh kebijakan hutang, kepemilikan manajerial, kebijakan dividen, dan ukuran perusahaan terhadap nilai perusahaan (studi pada sektor pertambangan yang terdaftar di BEI periode 2011-2014). Jurnal Ilmu Manajemen (JIM), 4(2). Google Scholar

Saputri, Aniyah Amalia, \& Winarto, Herry. (2019). Pengaruh Price Earning Ratio, Debt To Equity Ratio Dan Return On Equity Terhadap Harga Saham Pt. Mandom 
Pengaruh Struktur Kepemilikan Manajerial Perusahaan Terhadap Manajemen Laba

Indones, Tbk. Jurnal Ekonomi Dan Industri, 20(2). Google Scholar

Sari, Naomi Puspita, \& Khafid, Muhamad. (2020). Peran Kepemilikan Manajerial dalam Memoderasi Pengaruh Profitabilitas, Leverage, Ukuran Perusahaan, Kebijakan Dividen Terhadap Manajemen Laba pada Perusahaan BUMN. Jurnal Akuntansi Dan Keuangan, 7(2), 222-231. Google Scholar

Wimelda, Linda, \& Marlinah, Aan. (2013). Variabel-variabel yang mempengaruhi struktur modal pada perusahaan publik sektor non keuangan. Media Bisnis, 5(3), 200-213. Google Scholar

First publication right:

Jurnal Syntax Fusion: Jurnal Nasional Indonesia

This article is licensed under:

(ㅇ) (1) ( ) 